\title{
UPAYA MENINGKATKAN HASIL BELAJAR PESERTA DIDIK KELAS 2 SEKOLAH DASAR NEGERI PASIRGUNUNG SELATAN 4 KOTA DEPOK MATA PELAJARAN ILMU PENGETAHUAN SOSIAL (IPS) TEMA PERISTIWA PENTING DALAM KELUARGA MELALUI METODE DEMONSTRASI MENGGUNAKAN MEDIA AUDIO VISUAL
}

\author{
Nama : Endang Retnoningsih, ${ }^{1}$ \\ Guru SDN Pasirgunung Selatan 4 Kota Depok \\ Email : endangretningsih72@gmail.com \\ Wahyu Bagja Sulfemi ${ }^{2}$ \\ STKIP Muhammadiyah Bogor \\ surel:wahyubagja@gmail.com
}

\begin{abstract}
Abstrak
Penelitian Tindakan Kelas ini dilaksanakan di SDN Pasirgunung Selatan 4 Kota Kelasa 2 dengan jumlah peserta didik 30 orang. Tujuan penelitian ini untuk meningkatkan hasil belajar peserta didik kelas 2 pada mata pelajaran Ilmu Pengetahuan Sosial tentang Peristiwa Penting yang Pernah di Alami dikeluarga melalui metode demonstrasi menggunakan melalui media audio visual. Hasil pelaksanaan pembelajaran prasiklus dengan KKM 70 dari jumlah 30 Pada Prasilkus diperoleh hasil rerata peserta didik 62 yang belum mencapai KKM berjumlah $20(64 \%)$. Siklus 1 rerata peserta didik 68 belum mencapai KKM 13 (43\%). Pada siklus 2 hasil diperoleh rerata 81 yang belum mencapai KKM berjumlah 4 peserta didik atau atau $13 \%$. Sedangkan melalui pengamatan peserta didik yang dapat menjawab pertanyaan guru hanya 9 (30\%), siklus 1 didapat 16 orang (54\%), Siklus 2 didapat 28 orang peserta didik atau 93\% . Penerapan metode demonstrasi melalui media audio visual telah memberikan pengaruh yang sangat baik dengan meningkatkan hasi belajar dan motivasi peserta didik.
\end{abstract}

Kata-kata kunci: hasil belajar IPS, metode demonstrasi, audio vasual

\section{PENDAHULUAN}

\section{A. Latar Belakang Masalah}

Upaya peningkatkan sumberdaya manusia yang berkualitas, bidang pendidikan memegang peranan penting karena pendidikan akan dapat mengembangkan kemampuan serta meningkatkan mutu kehidupan bangsa Indonesia. Disamping itu akan terwujud sumber daya manusia yang terampil, potensial dan berkualitas sebagai pelaksana pembangunan dalam mewujudkan tujuan Nasional. 
Tujuan ini sejalan dengan tujuan dari mata pelajaran Ilmu Pengetahuan Sosial (IPS) dimana IPS bertujuan untuk membentuk warga negara yang baik, melatih peserta didik berkemampuan berpikir matang untuk menghadapi, dan memecahkan masalah sosial, dan agar peserta didik dapat mewarisi dan melanjutkan budaya bangsanya. Untuk mencapai tujuan ini maka hasil belajar peserta didik harus baik.

Akan tetapi berdasarkan pengamatan hasil observasi penelitian hasil belajar di Sekolah Dasar Negeri (SDN) Pasirgunung 4 Kecamatan Cimanggis Kota Depok kelas 2 Mata Pelajaran IPS tentang "Peristiwa Penting yang dalam Keluarga" dengan Kriteria Ketuntasan Maksimum (KKM) 70 diperoleh rata-rata peserta didik 62. Dari hasil tersebut peserta didik tidak mampu menerima informasi yang disampaikan sesuai dengan tujuan yang telah di tetapkan oleh guru dengan merujuk pada tidak tercapainya KKM Mata Pelajaran IPS

Rendahnya hasil belajar tersebut banyak faktor terutama factor guru dan peserta didik Guru sebagai komponen penting dalam proses belajar mengajar mempunyai peran yang sangat strategis dalam usaha pembentukan sumber daya manusia berkualitas. Dalam hal ini guru melaksanakan tugasnya baik sebagai perencana pengajaran, sebagai pelaksana, maupun sebagai evaluator pengajaran. Bahkan guru diharapkan memodifikasi rancangan dan pelaksanaan pengajaran, berperan aktif serta menempatkan kedudukannya sebagai tenaga profesional, sesuai dengan tuntutan masyarakat yang semakin berkembang untuk meningkatkan hasil belajar peserta didik sesuai dengan harapan.

Media pembelajaran yang digunakan oleh guru dalam proses pembelajaran memiliki andil untuk menjelaskan hal-hal yang abstrak dan menunjukan hal-hal yang tersembunyi. Ketidakjelasan atau kerumitan materi pembelajaran dapat dibantu dengan menghadirkan media sebagai perantara. Bahkan dalam hal-hal tertentu media dapat mewakili kekurangan guru dalam mengkomunikasikan materi pelajaran. Akan Tetapi, perlu diingat bahwa peranan media tidak akan terlihat apabila penggunaanya tidak sejalan dengan 
esensi tujuan pengajaran yang telah dirumuskan. Untuk itu tujuan pengajaran harus dijadikan sebagai pangkal acuan untuk menggunakan media.

Berdasarkan latar belakang masalah di atas, peneliti tertarik untuk mengadakan penelitian dengan judul Upaya Meningkatkan Hasil Belajar Peserta Didik Kelas 2 SDN Pasirgunung Selatan 4 Kota Depok Mata Pelajaran Ilmu Pengetahuan Sosial dengan Tema Peristiwa Penting Dalam Keluarga Melalui Metode Demonstrasi Menggunakan Media Audio Visual

\section{Identifikasi Masalah}

Berdasarkan dari latar belakang masalah tersebut, maka dapat di identifikasi masalah sebagai berikut :

a. Rendahnya hasil belajar peserta didik pada mata pelajaran IPS hal ini dilihat dari hasil rerata peserta didik yang tidak mencapai KKM yang ditetapkan

b. Rendahnya minat serta motivasi belajar peserta didik.

c. Peserta didik kurang fokus pada saat pembelajaran berlangsung

d. Peserta didik sangat pasif dalam menerima pelajaran ini.

e. Banyak peserta didik yang kesulitan memahami materi

\section{Analisa Masalah}

Berdasarkan identifikasi masalah di atas maka, di ketahui penyebab dari masalah ini adalah :

a. Penggunaa metode pembalajaran yang tidak menarik, bervariasi dan efektif yang sesuai secara maksimal sehingga peserta didik mengalami kesulitan

b. Tidak adanya penggunaan media pembelajaran yang membuat peserta didik merasa tertarik untuk belajar

c. Guru jarang mengadakan dan reward kepada umpan balik secara langsung selama pembelajaran, sehingga peserta didik tidak aktif

d. Guru kurang memberikan motivasi pada saat pembelajaran berlangsung sehingga peserta didik tidak tertarik pada pelajaran IPS

\section{Alternatif dan Prioritas Pemecahan Masalah}


Keberhasilan dari suatu proses pembelajaran untuk memenuhi keinginan dalam peningkatan kualitas di tentukan beberapa faktor, salah satu di antaranya adalah pemilihan media pembelajaran yang tepat untuk menunjang peningkatan minat belajar peserta didik yaitu dengan cara :

a. Guru sebaiknya menggunakan metode pembelajaran dan teknik pembelajaran yang bervariasi dan efektif

b. Guru sebaiknya menggunakan media pembelajaran yang sesuai secara maksimal sehingga terciptanya suasana pembelajaran yang kondusif, dan menyenangkan bagi peserta didik

c. Guru harus memberikan motivasi pada saat pembelajaran berlangsung sehingga peserta didik tertarik pada pelajaran IPS

d. Guru harus mengadakan reward dan umpan balik secara langsung selama pembelajaran, sehingga peserta didik tidak aktif.

\section{B. Rumusan Masalah}

Berdasarkan identifikasi dan analisis masalah yang dipaparkan di atas, dapat dirumuskan masalah adalah "bagaimana meningkatkan hasil belajar peserta didik kelas 2 SDN Pasirgunung Selatan 4 Kota Depok Mata Pelajaran Ilmu Pengetahuan Sosial dengan tema Peristiwa Penting Dalam Keluarga melalui metode demonstrasi dengan menggunakn media audio visual?

\section{Tujuan Penelitian Perbaikan Pembelajaran}

Berdasarkan uraian dari rumusan masalah setiap kegiatan penelitian yang di lakukan adalah untuk meningkatkan hasil belajar peserta didik kelas 2 SDN Pasirgunung Selatan 4 Kota Depok Mata Pelajaran Ilmu Pengetahuan Sosial dengan tema Peristiwa Penting Dalam Keluarga melalui metode demonstrasi menggunaan media audio visual?

\section{Manfaat Penelitian Perbaikan Pembelajara}

Manfaat penelitian perbaikan pembelajaran disusun dalam rangka peningkatan mutu pendidikan dan memberikan manfaat yang positif bagi berbagai pihak :

\section{Bagi peserta didik}



a. Meningkat Prestasi dan hasil belajar peserta didik
b. Dapat mengembangkan rasa kebersamaan dan kerja sama peserta didik dengan peserta didik lain.
c. Dapat memotivasi peserta didik untuk belajar lebih giat khususnya dalam pembelajaran IPS sehingga mengurangi kebosanan dalam belajar.
d. Membiasakan peserta didik berani tampil dan percaya diri.

\section{Bagi Guru}

a. Memperbaiki pembelajaran yang di kelola.

b. Dapat mengetahui masalah - masalah dan kesulitan yang di hadapi peserta didik dalam pembelajaran IPS.

c. Dapat meningkatkan kualitas pembelajaran.

\section{Bagi sekolah}

a. Hasil laporan penelitian ini dapat di gunakan sebagai tambahan referensi bagi rekan guru yang akan mengadakan penelitian.

b. Dapat memberikian perbaikan mutu pelajaran IPS Kelas 2 SDN Pasirgunung Selatan 4

\section{KAJIAN PUSTAKA}

\section{A. Hakekat Hasil Belajar}

Merujuk pada teori-teori belajar di atas, Burton (dalam Usman dan Setiawati, 2001: 4) mengemukakan hal yang sama dengan teori behaviorisme di mana belajar dapat diartikan sebagai perubahan tingkah laku pada diri individu berkat adanya interaksi antara individu dengan individu dan individu dengan lingkungannya sehingga mereka lebih mampu berinteraksi dengan lingkungannya. Kemudian Witherington (dalam Usman dan Setiawati, 2001: 5) menyatakan bahwa "Belajar adalah suatu proses perubahan di dalam kepribadian yang menyatakan diri sebagai suatu pola baru dari reaksi berupa kecakapan, sikap, kebiasaan kepribadian atau suatu pengertian”. Selanjutnya, Gagne (dalam Slameto, 2010: 13) memberikan dua definisi belajar, yakni: (1) belajar adalah suatu proses untuk memperoleh motivasi dalam pengetahuan, 
keterampilan, kebiasaan, dan tingkah laku; dan (2) belajar adalah penguasaan pengetahuan atau keterampilan yang diperoleh dari instruksi.

Hasil belajar merupakan kulminasi dari suatu proses yang telah dilakukan dalam belajar. Hasil belajar harus menunjukkan suatu perubahan tingkah laku atau perolehan perilaku yang baru dari siswa yang bersifat menetap, fungsional, positif dan disadari (Anitah, 20014: 2.19). Ada berbagai faktor yang dapat mempengaruhi proses dan hasil belajar siswa di sekolah yang secara garis bessarnya dapat dibagi dalam dua bagian yaitu faktor internal dan faktor eksternal siswa. (Sabri, 1995 : 59). Faktor-faktor yang berasal dari luar diri siswa (eksternal) terdiri dari faktor lingkungan dan faktor instrumental. Sedangkan faktor-faktor yang berasal dari dalam diri siswa (internal); adalah berupa faktor fisiologis dan psikologis pada diri siswa.

Melalui uraian para ahli di atas dapat dikatakan bahwa hasil belajar merupakan puncak kulminasi dari proses belajar mengajar. Dalam proses belajar ini di dalamnya terdapat proses pemasukan berupa informasi. Outputs yang diperoleh berupa perubahan tingkah laku atau perilaku yang baru yang bersifat positif dan disadari. Kualitas hasil belajar dapat dilihat dari hasil pengukuran berupa evaluasi

\section{B. Metode Demonstrasi}

Menurut Syah (2004:22) metode demonstrasi adalah metode mengajar dengan cara memperagakan barang, kejadian, aturan, dan urutan melakukan suatu kegiatan baik secara langsung maupun melalui penggunaan media pengajaran yang relevan dengan pokok bahasan atau materi yang sedang disajikan.

Menurut Anitah (2014:5.25) menjelaskan bahwa metode demonstrasi semata-mata digunakan hanya untuk :

1. Mengkongkritkan suatu konsep atau prosedur yang abstrak.

2. Mengajarkan bagaimana berbuat atau menggunakan prosedur secara tepat.

3. Meyakinkan bahwa alat dan prosedur tersebut bisa digunakan. 
4. Membangkitkan minat menggunakan alat prosedur.

Manfaat psikologis metode demonstrasi adalah :

1. Perhatian siswa dapat lebih dipusatkan.

2. Proses belajar siswa lebih terarah pada materi yang sedang dipelajari.

3. Pengalaman dan kesan sebagai hasil pembelajaran lebih melekat pada dirisiswa.

Menurut Anitah, (2014:5.25) menggunakan metode demonstrasi memiliki keunggulan sebagai berikut

1) Perhatian siswa dapat dipusatkan pada hal-hal yang dianggap penting oleh guru sehingga yang penting itu dapat diamati secara teliti.

2) Siswa dapat memehami bahan pelajaran sesuai dengan objek yang sebenarnya

3) Dapat mengembangkan rasa ingin tahu siswa.

4) Dapat melakukan pekerjaan berdasarkan proses yang sistimatis.

5) Ekonomis dalam jam pelajaran di sekolah dan ekonomi dalam waktu yang panjang dapat diperlihatkan melalui demonstrasi dengan waktu yang pendek.

6) Dapat mengurangi kesalahan-kesalahan bila dibandingkan dengan hanya membaca atau mendengarkan, karena murid mendapatkan gambaran yang jelas dari hasil pengamatannya.

7) Beberapa persoalan yang menimbulkan pertanyaan atau keraguan dapat diperjelas waktu proses demonstrasi.

Kelemahan metode ini adalah

1. Sering terjadi siswa kurang berani dalam mencoba atau Hanya dapat menimbulkan cara berfikir yang kongkrit saja.

2. Jika jumlah siswa banyak dan posisi siswa tidak diatur maka demonstrasi tidak efektif.

3. Bergantung pada alat bantu yang sebenarnya.

4. melakukan praktik yang didemonstrasikan .

5. Tidak semua hal dapat didemonstrasikan di kelas (Anitah, 2014:5.25). 
Jadi dari berbagai penjelasan di atas dapat disimpulkan bahwa Metode Demonstrasi merupakan metode mengajar yang menyajikan bahan pelajaran dengan mempertunjukkan secara langsung objek atau cara melakukan sesuatu sehingga dapat mempelajarinya dengan proses

\section{Media Audio visual}

Menurut Sumiati (2008:160) bentuk-bentuk media pembelajaran digunakan untuk meningkatkan pengalaman belajar agar menjadi lebih konkrit. Lebih lanjut Sumiati, (2008:160) Dalam proses belajar mengajar, kehadiran media mempunyai arti yang penting, karena dalam kegiatan tersebut ketidak jelasan bahan yang akan disampaikan dapat dibantu dengan menghadirkan media sebagai perantara. Kerumitan bahan yang akan disampaikan oleh guru kepada peserta didik dapat disederhanakan dengan bantuan media.

Suprijanto, (2005:171) menyampaikan media audio visual adalah media yang mempunyai unsur suara dan unsur gambar. Jenis media ini mempunyai kemampuan yang lebih baik, karena meliputi kedua jenis media auditif (mendengar) dan visual (melihat)._Media Audio visual merupakan sebuah alat bantu audio visual yang berarti bahan atau alat yang dipergunakan dalam situasi belajar untuk membantu tulisan dan kata yang diucapkan dalam menularkan pengetahuan, sikap, dan ide.

Pendapat berikutnya dikemukakan oleh Winn (1996) yang dikutip Amalia (2012:5.3) fungsi media antara lain adalah (1) menyampaikan pembelajaran, di mana media digunakan untuk menyampaikan materi pembelajaran tertentu, (2) konstruksi dari lingkungan di mana media membantu siswa menggali dan membangun pemahaman dari pengetahuan, dan (3) mengembangkan keterampilan kognitif, di mana media digunakan sebagai model, kreasi atau pengembangan dari keterampilan mental.

Belajar dengan menggunkan audio visual banyak sekali manfaatnya, karena dengan menggunakan audio visual dapat memperoleh pengalaman yang lebih banyak, mengesankan, lebih jelas, dan kongkrit. Di samping itu 
media audio visual mempunyai potensi pokok menurut Idger Dale dalam Pandie, (1984: 115) sebagai berikut:

1. Memberikan dasar-dasar kongkrit untuk berfikir.

2. Membuat pelajaran lebih menarik.

3. Memungkinkan hasil belajar lebih tahan lama.

4. Memberikan pengalaman-pengalaman yang nyata.

5. Mengembangkan keteraturan dan kontinuitas berfikir.

6. Dapat memberikan pengalaman-pengalaman yang tidak diperoleh dengan cara lain membuat kegiatan belajar lebih mendalam efisien dan beraneka ragam.

7. Media audio visual dapat dilakukan berulang-ulang (Pandie, 1984:115)

Kelemahan media audio visual adalah

1. Sering dianggap sebagai hiburan TV

2. Kegiatan melihat video adalah kegiatan pasif

3. Menggunakan video berarti memerlukan dua unit alat, yaitu VCD/DVD dan monitor TV

4. Harganya relatif mahal

5. Siswa tidak bias melihat secara cepat bagian-bagian tayangan yang sudah terlewatkan.

6. Tidak mudah dibawah kemana-mana, beberapa media pembelajaran audio visual yang memiliki ukuran besar, cukup menyulitkan untuk dibawa kemana-mana.

7. Membutuhkan listrik

8. Cepat rusak

Kelebihan dari media audio visual adalah

Dari uraian para ahli diatas maka penulis dapat mengambil kesimpulan bahwa media pembelajaran adalah suatu proses dimana terjadi interakasi antara guru dan murid. dengan cara menggunakan metode demontrasi dan media gambar pada audio visual sangat membantu siswa dalam perolehan nilai yang diinginkan, sehingga hasil yang didapat sesuai apa yang kita harapkan, agar nanti nya menjadi suatu pengalaman belajar 
yang lebih berarti bagi siswa. Media yang digunakan oleh penulis adalah dengan dengan menggunakan infokus

\section{Hakekat Pelajaran IPS di SD}

Istilah Ilmu Pengetahuan Sosial, disingkat IPS, menurut Supriya (2009:19) merupakan nama mata pelajaran di tingkat sekolah dasar dan menengah atau nama program studi di perguruan tinggi identik dengan istilah "social studies". Pemikiran mengenai konsep Ilmu Pengetahuan Sosial di Indonesia banyak dipengaruhi oleh pemikiran "sosial studies" di Amerika Serikat. Pilar historis-epistemologis, "Sosial Studies" pertama kali disampaikan oleh Edgar Bruce Wesley bahwa studi sosial adalah ilmu-ilmu yang disederhanakan untuk tujuan pendidikan (Barr, Bart dan Shermis, 1977: 1-2 dalam Winaputra 2010: 1.3).

Konsep IPS masuk ke dalam dunia pendidikan di Indonesia pada tahun 1972 - 1973, yakni dalam kurikulum IPS di Indonesia, jenjang pendidikan SD dan SMP, pendidikan IPS dilakukan secara terpadu, sementara pada jenjang SMA, pendidikan IPS sudah mulai di partisi menjadi beberapa bidang kajian, yaitu sejarah, ekonomi, sosiologi dan geografi. Pada kurikulum 1994 ditambah dengan bidang kajian tata negara dan antropologi. Dalam penelitian ini pendidikan IPS di SMA digunakan istilah bidang studi IPS dan mengacu pada kurikulum yang berlaku di SMA saat ini yaitu meliputi mata pelajaran sejarah, ekonomi, sosiologi dan geografi. Sedangkan dalam kurikulum KTSP tahun 2006 IPS di SMK adalah terpadu (Wahab, 2008: 2.19).

Kurikulum IPS tahun 2006 bertujuan agar peserta didik memiliki kemampuan sebagai berikut:

1. Mengenal konsep-konsep yang berkaitan dengan kehidupan masyarakat dan lingkungan.

2. Memiliki kemampuan dasar untuk berpikir logis dan kritis, rasa ingin tahu, memecahkan masalah, dan keterampilan dalam kehidupan sosial.

3. Memiliki komitmen dan kesadaran terhadap nilai-nilai sosial dan kemanusiaan. 
4. Memiliki kemampuan berkomunikasi, bekerja sama dan berkompetisi dalam masyarakat yan majemuk, di tingkat lokal, nasional, dan global (Sardiyo, 2009:1.26).

Berdasarkan pengertian hasil belajar IPS, disimpulkan bahwa hasil belajar adalah kemampuan-kemampuan yang dimiliki peserta didik setelah menerima pengalaman belajarnya dalam penyederhanaan, adaptasi, seleksi dan modifikasi diorganisasikan dari konsep-konsep ketrampilan-ketrampilan Sejarah, Geografi, Sosiologi, Antropologi, dan Ekonomi. kemampuan-kemampuan tersebut mencakup aspek kognitif, afektif, dan psikomotorik.

\section{PELAKSANAAN PENELITIAN PERBAIKAN PEMBELAJARAN}

\section{A. Subjek, Tempat, Waktu Penelitian dan Pihak yang Membantu}

Subjek penelitian adalah peserta didik kelas 1 yang berjumlah 30 Peserta didik terdiri dari sebagai 17 Laki- laki dan 13 Perempuan pada mata pelajaran IPS tentang "Peristiwa Penting Dalam Keluarga" Tempat penelitian ini dilakukan di SDN Pasirgunung Selatan 4 Jalan Pondok Pesantren Huda kelurahan Pasirgunung Selatan. Kecamatan Cimanggis Kota Depok. Penelitian ini dilaksanakan mulai hari Rabu tanggal, 20 Juli 2018 diawali dengan prasiklus yang menjadi sumber masalah yang ditemukan,

\section{B. Desain Prosedur Perbaikan Pembelajaran}

Dalam Penelitian ini dilaksanakan dua siklus yang masing-masing melalui 4 tahapan yaitu tahap perencanaan, pelaksanaan, pengamatan dan refleksi. Adapun pelaksanaan penelitian tersebut dideskripsikan sebagai berikut:

\section{Siklus 1}

\section{a. Persiapan}

1. Perencanaan pelaksanaan pembelajaran yang akan dilaksanakan pada hari, hari Rabu tanggal, 27 Juli 2018

2. Guru menyusunan Rencana Pembelajaran IPS dengan Tema Peristiwa Penting yang di Alami

3. Penyusunan metode pembelajaran berupa ceramah dan tanya jawab dan demontrasi 
4. Persiapan sumber belajar dan bahan ajar.

5. Penyusunan alat evaluasi pembelajaran atau lembar kerja peserta didik (LKS)

\section{b. Pelaksanaan}

1) Kegiatan awal (10 menit)

a) Guru mengajak peserta didik berdoa, mengisi daftar kelas, menulis hari dan tanggal di papan tulis dan mempersiapkan materi ajar.

b) Guru memperingatkan peserta didik cara duduk yang baik ketika menulis, membaca dan meluruskan barisan meja dan kursi mereka

c) Guru memberikan motivasi belajar kepada para peserta didik melalui "tepuk semangat” dan menyanyikan Lagu Halo-Halo Bandung

d) Guru memperlihatkan contoh peristiwa penting yang pernah dialami diikuti tanya jawab untuk mengetahui kemampuan awal peserta didik tentang apa yang akan dipelajari

e) Guru menyampaikan tujuan pembelajaran setelah pembelajaran peserta didik dapat menyebutkan Peristiwa Penting Dalam Keluarga

f) Guru menyampaikan topik yang akan dipelajari yaitu "Peristiwa Penting Dalam Keluarga"

g) Guru mengaitkan tofik dengan menyampaikan manfaat konsep tersebut dalam kehidupan sehari-hari

2) Kegiatan inti (40 menit)

a) Guru menyebutkan beberapa Peristiwa Penting yang di Alami

b) Guru meminta peserta didik memperhatikan gambar Peristiwa Penting yang di Alami Dalam keluarga

c) Guru menjelaskan kejadian yang telah terjadi peristiwa ada yang penting ada yang biasa saja ada yang masih kita ingat 
ada pula yang sudah kita lupa disertai dengan contoh bendabenda yang dibawa guru dan peserta didik

d) Guru meminta beberapa peserta didik untuk maju kedepan menyebutkan peristiwa penting yang alami di rumah dan di lingkungan sekitar atau sekolah

e) Guru memberikan kesempatan peserta didik untuk bertanya

3). Kegiatan Akhir (20 menit)

a) Guru bersama peserta didik menyimpulkan pembelajaran

b) Guru memberikan tugas berupa LKS terkait materi yang baru saja dipelajari.

c) Peserta didik mengerjakan tugas yang diberikan guru.

d) Guru memberian PR / tugas

e) Menutup pelajaran

\section{c. Pengamatan}

Berdasarkan pengamatan dan observasi saat guru mengajar, yang menjadi permasalahan dalam pembelajaran tersebut adalah:

1) Peserta didik kurang termotivasi dalam pembelajaran.

2) Nilai rata-rata kelas yang diperoleh 68 masih dibawah KKM Tanggung jawab peserta didik akan tugas masih rendah, saat diberikan tugas belum dilaksanakan dengan optimal.

3) Media yang digunakan dalam pembelajaran belum maksimal

4) Keterlibatan peserta didik dalam kegiatan pembelajaran masih kurang.

\section{d. Refleksi}

Dari pelaksanaan pembelajaran siklus I, ditemukan kekuatan dan kelemahan dalam tindakan perbaikan pembelajaran diantaranya:

1. Kekuatan

a) Pembelajaran lebih efektif dengan metode .

b) Guru sudah melibatkan peserta didik dalam pembelajaran

c) Peserta didik mulai antusias terhadap media yang digunakan

d) Pemahaman materi oleh peserta didik sedikit lebih baik. 
2. Kelemahan

a) Guru kurang memandu siswa

b) Aktiftas peserta didik belum semua terlibat

c) Belum semua peserta didik melakukan mengerti dengan tugasnya

d) Ruang kelas kurang kondusif karena masih ada anak yang sibuk dengan mengobrol.

e) Pembelajarn masih didominasi peserta didik yang aktif saja.

f) Perolehan hasil rata-rata kelas masih dibawah KKM yaitu diperoleh 68 masih dibawah KKM

\section{Siklus 2}

\section{a. Persiapan}

1) Perencanaan pelaksanaan pembelajaran yang akan dilaksanakan pada hari Rabu, tanggal 3 Agustus 2018

2) Pada pertemuan sebelumnya guru menugaskan peserta didik untuk membawa foto keluarga, foto copi akte kelahiran, piagam, mainan waktu kecil, dan rapor Taman Kanak-Kanak

3) Guru menyusunan Rencana Pembelajaran IPS dengan Tema Peristiwa Penting yang di Alami di Keluarga

4) Penyusunan metode pembelajaran berupa ceramah dan tanya jawab.

5) Persiapan sumber belajar dan bahan ajar.

6) Penyusunan alat evaluasi pembelajaran atau lembar kerja peserta didik (LKS)

\section{b. Pelaksanaan}

1) Kegiatan awal (10 menit)

a) Guru mengajak peserta didik berdoa, mengisi daftar kelas, menulis hari dan tanggal di papan tulis dan mempersiapkan materi ajar.

b) Guru memperingatkan peserta didik cara duduk yang baik ketika menulis, membaca dan meluruskan barisan meja dan kursi mereka 
c) Guru memberikan motivasi belajar kepada para peserta didik melalui "tepuk semangat" dan menyanyikan lagu "Pada Hari Minggu"

d) Guru memperlihatkan contoh peristiwa penting yang pernah dialami diikuti tanya jawab untuk mengetahui kemampuan awal peserta didik tentang apa yang akan dipelajari

e) Guru menyampaikan tujuan pembelajaran setelah pembelajaran peserta didik dapat menyebutkan Peristiwa Penting Dalam Keluarga

f) Guru menyampaikan topik yang akan dipelajari yaitu "Peristiwa Penting Dalam Keluarga"

g) Guru mengaitkan tofik dengan menyampaikan manfaat konsep tersebut dalam kehidupan sehari-hari

2) Kegiatan inti (40 menit)

a) Guru menyebutkan beberapa Peristiwa Penting yang di Alami

b) Guru menjelaskan kejadian yang telah terjadi peristiwa ada yang penting ada yang biasa saja ada yang masih kita ingat ada pula yang sudah kita lupa dengan perlihat tayangan dengan menggunakan LCD mengenai peristiwa penting yang pernah dialami

c) Guru meminta peserta didik memperhatikan memperhatikan tayangan Film Peristiwa Penting yang di Alami

d) Peserta didik diminta menyebutkan dan Peristiwa penting yang alami di rumah dan di lingkungan sekitar atau sekolah dengan media yang mereka bawa

e) Guru meminta beberapa peserta didik untuk maju kedepan menyebutkan peristiwa penting yang alami di rumah dan di lingkungan sekitar atau sekolah dengan media yang mereka bawa

f) Guru memberikan penguatan kepada peserta didik

g) Guru memberikan kesempatan peserta didik untuk bertanya 
3). Kegiatan Akhir (20 menit)

a) Guru bersama peserta didik menyimpulkan pembelajaran

b) Guru memberikan tugas berupa LKS terkait materi yang baru saja dipelajari.

c) Peserta didik mengerjakan tugas yang diberikan guru.

d) Guru memberian PR / tugas

e) Menutup pelajaran

\section{c. Pengamatan}

Peneliti melakukan pengamatan terhadap aktivitas peserta didik dalam mengikuti perbaikan pembelajaran dengan metode demonstrasi. Hasil pengamatan ternyata ada perubahan yang sangat berbeda karena peserta didik menjadi aktif, antusias, dan mengerti dengan jelas materi yang dipelajari. Hal itu berpengaruh dari hasil belajar yang meningkat dari Siklus I (nilai rerata 68) ke Siklus II (nilai rerata 81). Hal ini dikarena

a. Guru sudah menggunakan metode pembelajaran dan teknik pembelajaran yang bervariasi dan efektif

b. Guru sudah menggunakan media pembelajaran yang sesuai secara maksimal sehingga tidak terciptanya suasana pembelajaran yang kondusif, dan menyenangkan bagi peserta didik

c. Guru sudah memberikan motivasi pada saat pembelajaran berlangsung sehingga peserta didik tidak tertarik pada pelajaran IPS

d. Guru sudah mengadakan reward dan umpan balik secara langsung selama pembelajaran, sehingga peserta didik tidak aktif

\section{d. Refleksi}

Dalam melakukan refleksi perbaikan pembelajaran, penulis dan teman sejawat mencatat beberapa hal yang sangat berpengaruh pada penerapan metode demonstrasi melalui media gambar yaitu:

1) Dengan menggunakan metode demonstrasi, peserta didik mendapatkan suasan baru, sehingga dapat menghindari kebosanan dalam proses pembelajaran. 
2) Dengan metode demonstrasi, dapat membiasakan peserta didik untuk berkomunikasi aktif dalam bertukar fikiran dengan teman.

3) metode demonstrasi, peserta didik diajarkan untuk mandiri, dan memiliki rasa setia kawan yang tinggi.

4) Dengan metode demonstrasi pada perbaikan pembelajaran pada siklus II ini hasil nila rerata peserta didik sebesar 81 dan 24 dari 30 peserta didik (81\%)) yang mendapat nilai di atas KKM. Sedangkan Hasil pengamatan didapat data peserta didik yang dapat menjawab pertanyaan guru dengan benar sebanyak 24 dari 30 peserta didik atau sebesar $(80 \%)$

5) Dengan metode demonstrasi mendapatkan keuntungan, menambah pengalaman dan kepercayaan diri, peserta didik Pada akhirnya kualitas dan hasil belajar semakin membaik, sehingga tidak dilanjutkan dengan siklus berikutnya.

\section{Teknik Analisis Data}

Data yang telah dikumpulkan pada setiap kegiatan observasi dari pelaksanaan siklus penelitian dianalisis secara deskriptif dengan menggunakan teknik presentase untuk melihat kecenderungan yang terjadi dalam kegiatan pembelajaran mata pelajaran IPS.

Dalam pelaksanaan penelitian ini membutuhkan dua siklus perbaikan untuk mata pelajaran matematika. Pada proses perbaikan pembelajaran yang peneliti lakukan adalah melalui tiga tahapan, yaitu diantaranya adalah : perencanaan, pelaksanaan, pengamatan dan refleksi.

Langkah-langkah dalam teknik analisis data yang dilakukan adalah sebagai berikut:

1. Melaksanakan kegiatan pembelajaran, yang terdiri dari kegiatan prasiklus, siklus 1 , dan siklus 2 .

2. Mengumpulkan dan menganalisis nilai evaluasi pembelajaran dari tiap siklus.

3. Mendiskripsikan dan membandingkan nilai evaluasi dari tiap siklus.

4. Menentukan tingkat keberhasilan dari hasil evaluasi yang ditempuh dalam proses pembelajaran. 
5. Tes, yang digunakan untuk mendapatkan data tentang hasil belajar peserta didik.

6. Observasi, yang digunakan untuk mengumpulkan data tentang perkembangan keaktifan peserta didik dalam proses kegiatan belajar mengajar dengan menggunakan metode demonstrasi.

7. Diskusi dengan teman sejawat tentang keberhasilan dan kekurangan/kelemahan dalam pelaksanaan pembelajaran melalui metode pembelajaran diskusi dan tanya jawab dan merefleksikan hasil setiap siklus untuk perbaikan-perbaikan aktivitas dan praktek pembelajaran yang akan datang.

\section{HASIL PENELITIAN DAN PEMBAHASAN}

\section{A. Deskripsi Hasil Penelitian Perbaikan Pembelajaran}

Dalam pelaksanaan penelitian, peneliti telah dibantu oleh teman sejawat untuk mengamati pelaksanaan pembelajaran. Peneliti berdiskusi dengan supervisor untuk menemukan kekurangan-kekurangan dalam proses pembelajaran. Selain itu, peneliti telah melakukan refleksi atas pembelajaran yang dilakukan untuk melakukan perbaikan-perbaikan pada pembelajaran selanjutnya.

Dalam pelaksanaan pembelajaran pra siklus dengan KKM 70 di SDN SDN Pasirgunung Selatan 4 Kota Depok kelas 2 Mata Pelajaran IPS tentang “ Peristiwa Penting yang Dialami Dikeluarga" dari jumlah 30 peserta didik diperoleh hasil rerata peserta didik 62 dengan perincin data sebagai berikut jumlah nilai keseluruhan 1860, nilai tertinggi 100, dan nilai terendah 20, 10 orang peserta didik mencapai KKM atau 34\% sedangkan yang belum mencapai KKM berjumlah 20 peserta didik atau $64 \%$. Sedangkan melalui pengamatan peserta didik yang dapat menjawab pertanyaan guru hanya 9 peserta didik, atau sebesar 30\% sedangkan yang tidak dapat pertanyaan guru terdapat 21 orang peserta didik atau $70 \%$. Dalam kegiatan pembelajaran pada pra siklus ini sangatlah kurang memuaskan. 
Dalam pelaksanaan pembelajaran siklus 1 di SDN Pasirgunung Selatan 4 Kecamatan Cimanggis Kota Depok kelas 2 Mata Pelajaran IPS tentang “Peristiwa Penting yang Dialami Dikeluarga" dengan KKM 70 dari jumlah 30 peserta didik diperoleh hasil rerata peserta didik 68 dengan perincin sebagai berikut jumlah nilai keseluruhan 2030, nilai tertinggi 100, dan nilai terendah 30, peserta didik mencapai KKM berjumlah 17 atau 56\%, sedangkan yang belum mencapai KKM berjumlah 13 peserta didik atau $43 \%$. Melalui data pengamatan peserta didik yang dapat menjawab pertanyaan guru hanya ada 16 orang peserta didik atau 54\% sedangkan yang tidak dapat pertanyaan guru terdapat 14 peserta didik atau sebesar $46 \%$.

\section{B. Pembahasan Hasil Penelitian Perbaikan Pembelajaran}

Dalam pelaksanaan pembelajaran prasiklus dengan KKM 70 di SDN SDN Pasirgunung Selatan 4 Kota Depok kelas 2 Mata Pelajaran IPS tentang “ Peristiwa Penting yang Dialami Dikeluarga". Penulis mengunnakan metode ceramah dengan media hanya papan tulis. Hasil dari Prasiklus diperoleh hasil rerata peserta didik 62, 10 orang peserta didik mencapai KKM atau $34 \%$ sedangkan yang belum mencapai KKM berjumlah 20 peserta didik atau $64 \%$. Sedangkan melalui pengamatan peserta didik yang dapat menjawab pertanyaan guru hanya 9 peserta didik, atau sebesar 30\% sedangkan yang tidak dapat pertanyaan guru terdapat 21 orang peserta didik atau $70 \%$. Dalam kegiatan pembelajaran pada pra siklus ini sangatlah kurang memuaskan.

Pada pembelajaran prasiklus ini nilai rerata pembelajaran IPS di bawah KKM sehingga hasil belajar masih rendah. Hal berikutnya adalah peserta didik kurang termotivasi dalam pembelajaran, peserta didik menjadi pasif dan tanggung jawab peserta didik terhadap tugas masih rendah. Penyebab faktor tersebut disebababkan karena (1) Guru belum menggunakan media pembelajaran yang sesuai secara maksimal sehingga tidak terciptanya suasana pembelajaran yang kondusif, dan menyenangkan bagi peserta didik. (2) Guru belum menggunakan metode pembelajaran dan teknik pembelajaran yang bervariasi dan efektif (3) Guru kurang memberikan motivasi pada saat 
pembelajaran berlangsung sehingga peserta didik tidak tertarik pada pelajaran IPS . (4) Guru jarang mengadakan reward dan umpan balik secara langsung selama pembelajaran, sehingga peserta didik tidak aktif.

Setelah nilai rerata prasiklus kurang memuasakan maka dilanjutkan dengan siklus 1 . Untuk itu penulis merubah metode pembelajaran menjadi menjadi metode ceramah dan demostrasi dengan menggunakan media gambar. Pada pembelajaran siklus 1 diperoleh hasil rerata peserta didik 68 dengan perincin sebagai berikut jumlah nilai keseluruhan 2030, nilai tertinggi 100, dan nilai terendah 30, peserta didik mencapai KKM berjumlah 17 atau 56\%, sedangkan yang belum mencapai KKM berjumlah 13 peserta didik atau 43\%. Melalui data pengamatan peserta didik yang dapat menjawab pertanyaan guru hanya ada 16 orang peserta didik atau 54\% sedangkan yang tidak dapat pertanyaan guru terdapat 14 peserta didik atau sebesar $46 \%$. Walaupun ada ada peningkatan tetapi rerata peserta didik belum mencapai KKM. Sehingga harus melakukan perbaikan pembelajaran lagi

Penyebab rendahnya hasil belajar peserta didik pada siklus I adalah adalah guru belum melalukan hal berikut ini .

1. Belum menggunakan media pembelajaran yang sesuai secara maksimal sehingga tidak terciptanya suasana pembelajaran yang kondusif, dan menyenangkan bagi peserta didik

2. Kurang memberikan motivasi pada saat pembelajaran berlangsung sehingga peserta didik tidak tertarik pada pelajaran IPS

3. Belum mengadakan reward dan umpan balik secara langsung selama pembelajaran, sehingga peserta didik tidak aktif.

Dengan demikian maka peneliti melakukan penelitian pada siklus 2 . Untuk mengatasi permasalah di siklus 1 maka peneliti melakukan sebagai berikut :

Menggunakan metode pembalajaran ceramah dengan demostrasi menggunakan media audio visual pembelajaran yang sesuai secara maksimal sehingga Pada penulis mengunnakan metode ceramah dengan media hanya papan tulis 
1. Memberikan motivasi pada saat pembelajaran berlangsung sehingga peserta didik tidak tertarik pada pelajaran IPS

2. Mengadakan reward dan umpan balik secara langsung selama pembelajaran, sehingga peserta didik tidak aktif.

Pada pelaksanaan pembelajaran siklus 2 di SDN Pasirgunung Selatan 4 Kecamatan Cimanggis Kota Depok kelas 2 Mata Pelajaran IPS tentang “ Peristiwa Penting yang Dialami Dikeluarga" dengan KKM 70 dari jumlah 30 peserta didik diperoleh hasil rerata peserta didik 81 dengan perincin sebagai berikut jumlah nilai keseluruhan 2745, nilai tertinggi 100, dan nilai terendah 30, peserta didik mencapai KKM berjumlah 26 orang atau $87 \%$ sedangkan yang belum mencapai KKM berjumlah 4 peserta didik atau atau $13 \%$. Melalui data pengamatan peserta didik yang dapat menjawab pertanyaan guru berjumlah 28 orang peserta didik atau 93\% sedangkan yang tidak dapat pertanyaan guru terdapat 2 orang peserta didik atau $0,7 \%$

Dalam kegiatan pembelajaran pada siklus 2 ini peserta didik sangat berminat dan termotivasi untuk mengikuti pelajaran IPS. Hal ini di sebabkan karena tersedianya media yang tepat dan sesuai dengan materi yang di ajarkan oleh guru selama proses belajar mengajar berlangsung, sehingga tercipta suasana pembelajaran yang menantang, merangsang dan menyenangkan bagi peserta didik

Ketika peneliti menggunakan media audio visual yang menarik hampir seluruh peserta didik maju ke depan ingin melihat lebih dekat media audio visual yang peneliti gunakan meskipun tanpa maju ke depan pun sudah tampak jelas tetapi para peserta didik ingin lebih puas lagi melihatnya setelah peneliti menggunakan media pembelajaran yang menarik yaitu memberikan latihan soal yang sesuai dari materi penjelasan peneliti pada siklus 2 ini yaitu dengan memasangkan gambar, peneliti pun sangat senang sekali karena proses pembelajaran yang dilakukan dalam 2 siklus ini memberikan hasil yang baik, dan peneliti pun menyadari bahwa perlu menggunakan media yang menarik mungkin agar para mendapatkan hasil yang di harapkan dan membuat suasana yang lebih menyenangkan karena untuk tingkatan kelas 
rendah perlu melakukan kelas yang menyenangkan yaitu dengan sebuah permainan sebelum memulai pembelajaran agar para peserta didik pun nantinya dalam penerimaan pembelajaran akan lebih memahami

Peran guru tidak kalah pentingnya dalam menggerakan minat belajar peserta didik. Salah satu yang di gunakan yaitu dengan menyediakan sumber dan media pembelajaran yang tepat dan sesuai serta melibatkan peserta didik dalam proses pembelajaran berlangsung. Mengenal dan sanggup menggunakan metode mengajar adalah kemampuan dasar guru yang paling utama dalam meraih sukses di sekolah. Guru yang tidak mengenal metode mengajar jangan diharapkan bisa melaksanakan tugas mengajar dengan baik. Penguasaan materi menjadi landasan pokok seorang guru untuk memiliki kemampuan mengajar dan menguasai materi dengan baik senantiasa mencoba berbagai metode untuk diterapkan sesuai dengan perkembangan situasi di kelas dan tidak terlalu terikat dengan patokan persiapan mengajar. pembelajaran perlu membuat kondisi kelas yang menyenangkan dan tidak membosankan karena apabila para peserta didik dalam selama proses pembelajaran membosankan maka akan mendapatkan hasil yang tidak sesuai tujuan pembelajarn

\section{KESIMPULAN DAN SARAN TINDAK LANJUT}

\section{A. Kesimpulan}

Berdasarkan hasil Penelitian Tindakan Kelas (PTK) melalui aktivitas perbaikan pembelajaran yang telah dilaksanakan mulai dari prasiklus, siklus I sampai dengan siklus II pada mata pelajaran IPA, penulis dapat menarik kesimpulan sebagai berikut :

1. Hasil pelaksanaan pembelajaran prasiklus dengan KKM 70 di SDN Pasirgunung Selatan 4 Kota Depok kelas 2 Mata Pelajaran IPS tentang “ Peristiwa Penting yang Dialami Dikeluarga" dari jumlah 30 Pada Pra silkus diperoleh hasil rerata peserta didik 62 yang belum mencapai KKM berjumlah $20(64 \%)$. Siklus 1 rerata peserta didik 68 belum mencapai KKM 13 (43\%). Pada siklus 2 hasil diperoleh rerata 81 yang belum 
mencapai KKM berjumlah 4 peserta didik atau atau 13\%. Sedangkan melalui pengamatan peserta didik yang dapat menjawab pertanyaan guru hanya $9(30 \%)$, siklus 1 didapat 16 orang (54\%), Siklus 2 didapat 28 orang peserta didik atau $93 \%$

2. Dengan demikian penerapan metode demonstrasi melalui media audio visual telah memberikan pengaruh yang sangat baik dengan meningkatkan hasil belajar dan motivasi peserta didik untuk belajar menjadi meningkat. Sehingga materi yang disampaikan guru dapat dimengerti. Tanggung jawab peserta didik terhadap tugas menjadi tinggi, serta membantu peserta didik untuk terlibat aktif di dalam kelas dan

\section{B. Saran Tindak Lanjut}

Berdasarkan pada kesimpulan diatas ada beberapa hal yang sebaiknya dilakukan guru dalam upaya meningkatkan hasil belajar peserta didik.

1. Motivasi yang kuat sangat dibutuhkan oleh seorang peserta didik sebelum melakukan pembelajaran.

2. Suasana belajar yang aktif di dalam kelas akan memotivasi peserta didik dalam belajar.

3. Penggunaan metode demonstrasi melalui Media Audio visual dapat membantu peserta didik untuk lebih cepat memahami konsep materi pelajaran. Dalam hal ini metode demonstrasi dapat menjadi alternatif yang digunakan guru dalam mengajarkan pembelajaran IPS.

4. Memberikan kesempatan kepada peserta didik untuk lebih aktif di kelas, mengeluarkan pendapat untuk menumbuhkan rasa percaya diri serta keberanian anak dalam menjawab pertanyaan

\section{DAFTAR PUSTAKA}

Anitah W, Sri dkk, 2014, Strategi Pembelajaran di SD, Tanggerang Selatan : Universitas Terbuka

Amalia, Sapriati. ((2012). Pembelajaran IPA di SD. Jakarta: Universitas Terbuka

Badar, Dadan Samsul dan Sulfemi, Wahyu Bagja. (2014). Pengaruh Rasa Percaya Diri dan Motivasi Berprestasi Terhadap Kinerja di Kecamatan Ciampea Kabupaten Bogor. Edutecno. 10 (1), 1-10,

Djamarah, (2000), Strategi belajar mengajar, Jakarta:Rineka Cipta 
Fajartriani, Tia dan Sulfemi, Wahyu Bagja. (2014). Pengaruh Motivasi Kerja Guru dan Iklim Organisasi Terhadap Kinerja Guru SMA Negeri di Kecamatan Cigudeg. Edutecno. 8 (1), 17-26.

Hamalik, Oemar. (2006). Proses Belajar Mengajar. Jakarta: PT Bumi Aksara

Jihad Asep, Abdul Haris. (2013). Evaluasi Pembelajaran. Yogyakarta: Multi Pressindo

Kurnia, Inggridwati, dkk. 2007. Pekembangan Belajar Peserta Didik. Jakarta: Direktorat Jenderal Pendidikan Tinggi Departemen Pendidikan Nasional

Pandie, Imansjah Ali. (1984). Didaktik Metodik, Surabaya : PT. Usaha Nasional

Sardiyo, dkk. (2009). Pendidikan IPS di SD. Tanggerang Selatan : UniversitasTerbuka

Sabri, Alisuf. (1995). Psikologi Pendidikan. Jakarta : Pedoman Ilmu Jaya

Sumiati. (2008). Metode Pembelajaran . Bandung: CV Wacana Prima

Sapriya. (2009). Pendidikan IPS. Bandung: PT Remaja Rosda Karya.

Slameto. (2010), Belajar dan Fakta yang mempengaruhinya. Jakarta : Rineka Cipta

Sudjana, Nana. (2010). Penilaian Hasil Proses Belajar Mengajar. (Cet. XV). Bandung: PT. Ramaja Rosdakarya

Suprijanto, (2005), Pendidikan Orang Dewasa, Jakarta: PT.Bumi Aksara,

Supardi, (2012), Penelitian Tindakan Kelas, Jakarta : Bumi Aksara

Syah, Muhibbin. (2004), Psikologi Pendidikan dengan Pendekatan Baru. Bandung : Remaja Rosdakarya

Sulfemi, Wahyu Bagja. (2013). Pengaruh Persepsi Siswa atas Kemampuan Pedagogik Guru dan Motivasi Belajar Siswa Terhadap Prestasi Belajar Ilmu Pengetahuan Sosial Siswa (Survei di SMK Swasta Kabupaten Bogor). Edutecno. 7 (2), 17-26.

Sulfemi, Wahyu Bagja. (2014). Pengaruh Motivasi dan Lingkungan Sekolah Terhadap Prestasi Belajar Sejarah Di SMA Negeri Leuwilang Kabupaten Bogor. Fascho : Kajian Pendidikan dan Sosial Kemasyarakatan 9 (2), 42-52

Sulfemi, Wahyu Bagja. (2015). Pengaruh Metode Pembelajaran Kontekstual dan Penggunaan Media Video Pendidikan Terhadap Hasil Belajar IPS. Edutecno 13 (2), 1-10

Sulfemi, Wahyu Bagja. (2016). Hubungan Persepsi Peserta Didik Tentang Kompetensi Guru Mata Pelajaran Sejarah dengan Hasil Belajar Mata 
Pelajaran Sejarah di Kelas X SMA Negeri 1 Pamijahan Kabupaten Bogor. Fascho, 5 (2), 52-70

Sulfemi, Wahyu Bagja. (2016). Hubungan antara Persepsi Guru pada Kepemimpian Kepala Sekolah dan Motivasi Guru dengan Kinerja guru dalam Proses Pembelajaran di SMA Negeri 1 Ciomas. Fascho : Kajian Pendidikan dan Sosial Kemasyarakatan, 5 (1), 36-55

Sulfemi, Wahyu Bagja. (2016). Perundang-Undangan Pendidikan. Bogor : Program Studi Administrasi Pendidikan STKIP Muhammadiyah Bogor.

Sulfemi, Wahyu Bagja dan Lestari, Ayu Hopilatul. (2017). Korelasi Kompetensi Pedagogik Guru dengan Prestasi Belajar Mata Pelajaran IPS Di SMP Muhammadiyah Pamijahan Kabupaten Bogor. Edutecno. 16 (1), 116

Sulfemi, Wahyu Bagja dan Abdul Qodir. (2017). Hubungan Kurikulum 2013 Dengan Motivasi Belajar Peserta Didik Di SMK Pelita Ciampea. Edutecno 17 (2), 1-8.

Sulfemi, Wahyu Bagja. (2017). Analisis Pengaruh Motivasi Dan Disiplin Terhadap Kinerja Guru (Studi Kasus di SMA Negeri 1 Pamijahan Kabupaten Kabupaten Bogor). Prosiding Seminar Nasonal STKIP Muhammadiyah Bogor. 1 (1), 342-357

Sulfemi, Wahyu Bagja dan Supriyadi, Dede. (2018). Pengaruh Kemampuan Pedagogik Guru dengan Hasil Belajar IPS. Edutecno 17 (1), 1-10.

Uno, Hamzah B., Abdul Karim Rauf, dan Najamuddin Petta Solong. (2008). Pengantar Teori Belajar dan Pembelajaran. (Cet. II). Gorontalo: Nurul Jannah.

Usman, Moh Uzer dan Lilis Setiawati. (2001). Upaya Optimalisasi Kegiatan Belajar Mengajar. Bandung: Remaja Rosdakarya

Yusfiriadi, Yusfitriadi dan Sulfemi, Wahyu Bagja. (2012). Penyelewangan Dana Dalam Dunia Pendidikan. Fascho 1 (1), 1-9

Wahab, Abdul Azis (2008). Konsep Dasar IPS. Jakarta : Universitas Terbuka

Winataputra, S Udin.(2010). Stategi Belajar Mengajar. Jakarta: Universitas Terbuka.

, (2015). Materi dan Pembelajarn IPS SD. Jakarta : Universitas Terbuka

Winkel, W.S. (1996). Psikologi Pengajaran, Edisi yang Disempurnakan, Cetakan ke-4 Jakarta :Grasindo. 